\title{
TINGKAT KEPUASAN MAHASISWA TERHADAP PELAYANAN PENDIDIKAN DI JURUSAN KEBIDANAN PROGRAM STUDI KEBIDANAN CIREBON POLITEKNIK KESEHATAN KEMENTERIAN KESEHATAN TASIKMALAYA
}

\author{
Pepi Hapitria $^{1}$, Elit Pebryatie ${ }^{2}$, Yevi Dwi Ariyanti ${ }^{3}$ \\ 1,2,3 Dosen Jurusan Kebidanan Poltekkes Tasikmalaya
}

\begin{abstract}
ABSTRAK
Tujuannya penelitian ini mengetahui tingkat kepuasan mahasiswa terhadap pelayanan pendidikan di Program Studi Kebidanan Cirebon Tahun 2014.Jenis penelitian ini deskriptif dengan pendekatan kuantitatif, sedangkan metodologinya adalah crossectional. Sampel diambil dengan teknik Purposive Sampling dan subjek penelitian adalah mahasiswa yang aktif di semester ganjil dan telah melewati satu semester penuh saat pengambilan data, dengan jumlah 149 mahasiswa. Pengumpulan data dilakukan dengan penyebaran kuesioner. Analisis data menggunakan analisis deskriptif dan model SERVQUAL. Hasil penelitian menunjukkan sebagian besar persepsi mahasiswa terhadap pelayanan pendidikan adalah cukup yaitu $53.4 \%$, sebagian besar harapan mahasiswa terhadap pelayanan pendidikan adalah sangat tinggi yaitu $98.7 \%$ dan kepuasan mahasiswa terhadap pelayanan pendidikan sebagian besar ada pada kategori tidak puas sebanyak $99.2 \%$. Persepsi mahasiswa terhadap pelayanan pendidikan sebagian besar cukup. Harapan mahasiswa terhadap pelayanan pendidikan sebagian besar adalah sangat tinggi. Kepuasan mahasiswa terhadap pelayanan pendidikan di Prodi Kebidanan Cirebon sebagian besar ada pada kategori tidak puas. Saran Meningkatkan pelayanan pendidikian dari semua dimensi.
\end{abstract}

Kata Kunci : Persepsi, Harapan, Tingkat Kepuasan

\begin{abstract}
The aim of the study was determine the level of student satisfaction on educational services in Cirebon Midwifer Study Program 2014. This was a descriptive study with a quantitative approach and a cross-sectional methodology. The samples were taken by purposive sampling technique The subject were students who were active in the first semester and had gone through a full semester while collecting data, with a number of 149 students. The data was collected through questionnaires. The data analysis used descriptive analysis and SERVQUAL model analysis. The study showed that most of the students' perceptions of educational services were moderate (53.4\%), most of the students' expectations to educational services were very high (98.7\%) and most of student satisfactions to educational services were in the category of not satisfied as much as $99.2 \%$. Most of the students' perceptions of educational services were moderate. Most of the students' expectations to educational services were very high. Most of student satisfactions to educational services in the Midwifery Program of Cirebon were in the category of not satisfied. The institution is then expected to improve its educational services in all dimensions.
\end{abstract}

Keywords : Perceptions, Expectations, Satisfaction 


\section{PENDAHULUAN}

Pendidikan memainkan peranan sangat penting dan strategis dalam pembangunan nasional, untuk mencapai bangsa yang maju, mandiri, dan beradab. Menyadari akan pentingnya pendidikan bagi seluruh anak bangsa, Pemerintah terus berupaya memenuhi hak setiap warga negara dalam memper oleh layanan pendidikan untuk meningkatkan kualitas hidup bangsa.

Menurut Ardi (2012) mengungkapkan bahwa kesadaran masyarakat terhadap pendidikan mulai tinggi, hal ini akan berpengaruh terhadap persaingan diantara penyedia layanan pendidikan.Ketatnya persaingan dalam pelayanan pendidikan mengakibatkan penyedia layanan berlombalomba dalam memperoleh dan mempertahankan pelanggan, dalam hal ini adalah siswa. Salah satu cara yang ditempuh oleh penyedia layanan adalah dengan cara meningkatkan kualitas pelayanan. Didasari dengan adanya kualitas pelayanan yang baik maka akan menciptakan kepuasan bagi siswa. Kepuasan pelanggan berkontribusi pada sejumlah aspek krusial seperti

\section{METODE PENELITIAN}

Jenis penelitian deskriptif dengan pendekatan kuantitatif, metodologinya adalah crossectional. Instrumen pada pendekatan kuantitatif dengan menggunakan kuesioner tingkat kepuasan mahasiswa yang digunakan oleh Poltekkes Kemenkes Tasikmalaya berupa pernyataan, dan pertanyaan terbuka yang selanjutnya disesuaikan dengan model SERVQUAL. Populasi seluruh mahasiswa yang aktif secara akademis di semester ganjil Tahun Akademik 2014/2015 sejumlah 181 orang. Sampel adalah mahasiswa aktif di Tahun akademik 2014/2015 yang telah melewati satu semester penuh di semester ganjil ( tingkat I dan II). Pengambilan sampel secara accidental sampling, dan jumlah sampel 149 mahasiswa. Data primer yang terciptanya loyalitas pelanggan, meningkatkan reputasi instansi, berkurangnya elastisitas harga, berkurangnya biaya transaksi masa depan dan meningkatnya efisiensi dan produktifitas karyawan (Tjiptono, 2011).

Mengingat pelayanan pendidikan mempengaruhi daya saing, maka instansi pendidikan harus sudah mulai memikirkan pentingnya kepuasan pelanggan melalui pelayanan pelanggan secara lebih matang. Pada tahun akademik 2014/2015 sebagai upaya untuk mengevaluasi mutu pelayanan pendidikan, maka diperlukan pengukuran tingkat kepuasan pemakai jasa pelayanan dalam hal ini adalah mahasiswa. karena menurut Srinadi (2008) menyatakan bahwa pengukuran tingkat kepuasan pelanggan merupakan elemen penting dalam menyediakan pelayanan yang lebih baik, lebih efisien, dan lebih efektif. Untuk itu pelayanan pendidikan harus dimulai dari kebutuhan konsumen kan pelayanan dan berakhir pada tingkat kepuasan konsumen akan mutu pelayanan yang diberikan.

digunakan adalah kuesioner yang peneliti susun sesuai dengan lima dimensi SERVQUAL, yaitu Tangible, Reliability, Responsiveness, Assurance, dan Empathy.

Pengolahan data melalui tahap-tahap editing, coding, entry, cleaning dan tabulating. Untuk persepsi dengan kode yaitu sangat setuju (5), setuju (4), kurang setuju (3), tidak setuju (2) dan sangat tidak setuju (1) sedangkan pengkodean untuk harapan yaitu sangat mengharapkan (5), mengharapkan (4), kurang mengharapkan (3), tidak mengharapkan (2) dan sangat tidak mengharapkan (1),

Analisis data menggunakan teknik statistik deskriptif dan analisis model SERVQUAL dengan rumus sebagai berikut :

Skor SERVQUAL = Skor Persepsi - Skor Harapan

Sumber: Zeithaml, et al., 1990 dalam Tjiptono (2011) 
Hasil dari skor SERVQUAL ini dapat dikategorikan kedalam tiga kategori yaitu Sangat puas apabila hasil skor SERVQUAL menunjukan hasil positif $(+)$, Puas apabila hasil skor SERVQUAL menunjukan hasil nol (0) dan tidak puas apabila hasil skor SERVQUAL menunjukan hasil negative (-).

\section{HASIL PENELITIAN}

Tabel 1. Distribusi Frekuensi Persepsi Mahasiswa Terhadap Pelayanan Pendidikan Berdasarkan Dimensi Kualitas Pelayanan

\begin{tabular}{|c|c|c|c|c|c|c|c|c|c|c|c|c|c|}
\hline \multirow{3}{*}{ No } & \multicolumn{13}{|c|}{ Pelayanan Pendidikan } \\
\hline & \multirow[t]{2}{*}{$\begin{array}{c}\text { Persepsi } \\
\text { Mahasiswa }\end{array}$} & \multicolumn{2}{|c|}{ Reliabilitas } & \multicolumn{2}{|c|}{$\begin{array}{c}\text { Daya } \\
\text { Tanggap }\end{array}$} & \multicolumn{2}{|c|}{ Jaminan } & \multicolumn{2}{|c|}{ Empati } & \multicolumn{2}{|c|}{ Bukti Fisik } & \multicolumn{2}{|c|}{ Total } \\
\hline & & $\mathbf{n}$ & $\%$ & $\mathbf{n}$ & $\%$ & $\mathbf{n}$ & $\%$ & $\mathbf{n}$ & $\%$ & $\mathbf{n}$ & $\%$ & $\mathbf{n}$ & $\%$ \\
\hline 1. & Baik & 3 & 2.01 & 6 & 3.3 & 7 & 4.7 & 0 & 0 & 1 & 0.7 & 17 & 2.3 \\
\hline 2. & Cukup & 84 & 56,4 & 112 & 75.2 & 81 & 54.4 & 4 & 2.6 & 117 & 78.5 & 398 & 53.4 \\
\hline 3. & Kurang & 62 & 41,6 & 32 & 21.5 & 61 & 40.9 & 145 & 97.3 & 31 & 20.8 & 331 & 44.4 \\
\hline & Jumlah & 149 & 100 & 149 & 100 & 149 & 100 & 149 & 100 & 149 & 100 & 745 & 100 \\
\hline
\end{tabular}

Berdasarkan Tabel 1, sebagian besar persepsi mahasiswa terhadap pelayanan pendidikan cukup yaitu $53.4 \%$. Untuk dimensi pelayanan reliabilitas cukup 84
(56.4\%), daya tanggap cukup 112 (75.2\%), jaminan cukup 81 (54.4\%), empati kurang 145 (97.3\%) dan bukti fisik cukup 117 (78.5\%).

Tabel 2. Distribusi Frekuensi Harapan Mahasiswa Terhadap Pelayanan Pendidikan Berdasarkan Dimensi Kualitas Pelayanan

\begin{tabular}{|c|c|c|c|c|c|c|c|c|c|c|c|c|c|}
\hline \multirow{3}{*}{ No } & \multirow{3}{*}{$\begin{array}{c}\text { Harapan } \\
\text { Mahasiswa }\end{array}$} & \multicolumn{10}{|c|}{ Pelayanan Pendidikan } & & \\
\hline & & \multicolumn{2}{|c|}{ Reliabilitas } & \multicolumn{2}{|c|}{$\begin{array}{c}\text { Daya } \\
\text { Tanggap }\end{array}$} & \multicolumn{2}{|c|}{ Jaminan } & \multicolumn{2}{|c|}{ Empati } & \multicolumn{2}{|c|}{ Bukti Fisik } & \multicolumn{2}{|c|}{ Total } \\
\hline & & $\mathbf{n}$ & $\%$ & $\mathbf{n}$ & $\%$ & $\mathbf{n}$ & $\%$ & $\mathbf{n}$ & $\%$ & $\mathbf{n}$ & $\%$ & $\mathbf{n}$ & $\%$ \\
\hline 1. & $\begin{array}{l}\text { Sangat } \\
\text { Tinggi }\end{array}$ & 148 & 99.3 & 146 & 97.9 & 147 & 98.7 & 146 & 97.9 & 148 & 99.3 & 735 & 98.7 \\
\hline 2. & Tinggi & 1 & 0.67 & 3 & 2.01 & 2 & 1.32 & 3 & 2.01 & 1 & 0.67 & 10 & 1.34 \\
\hline 3. & Rendah & 0 & 0 & 0 & 0 & 0 & 0 & 0 & 0 & 0 & 0 & 0 & 0 \\
\hline & Jumlah & 149 & 100 & 149 & 100 & 149 & 100 & 149 & 100 & 149 & 100 & 745 & 100 \\
\hline
\end{tabular}

Tabel 3. Distribusi Frekuensi Tingkat Kepuasan Mahasiswa Terhadap Pelayanan Pendidikan

\begin{tabular}{|c|c|c|c|c|c|c|c|c|c|c|c|c|c|}
\hline \multirow{3}{*}{ No } & \multirow{3}{*}{$\begin{array}{c}\text { Tingkat } \\
\text { Kepuasan } \\
\text { Mahasiswa }\end{array}$} & \multicolumn{10}{|c|}{ Pelayanan Pendidikan } & & \\
\hline & & \multicolumn{2}{|c|}{ Reliabilitas } & \multicolumn{2}{|c|}{$\begin{array}{c}\text { Daya } \\
\text { Tanggap }\end{array}$} & \multicolumn{2}{|c|}{ Jaminan } & \multicolumn{2}{|c|}{ Empati } & \multicolumn{2}{|c|}{ Bukti Fisik } & \multicolumn{2}{|c|}{ Total } \\
\hline & & $\mathbf{n}$ & $\%$ & $\mathbf{n}$ & $\%$ & $\mathbf{N}$ & $\%$ & $n$ & $\%$ & $\mathbf{N}$ & $\%$ & $\mathbf{n}$ & $\%$ \\
\hline 1. & Sangat Puas & 0 & 0 & 1 & 0,7 & 0 & 0 & 0 & 0 & 0 & 0 & 1 & 0.13 \\
\hline 2. & Puas & 0 & 0 & 0 & 0 & 1 & 0.67 & 4 & 2.68 & 0 & 0 & 5 & 0.67 \\
\hline 3. & Tidak Puas & 149 & 100 & 148 & 99,3 & 148 & 99.3 & 145 & 97.3 & 149 & 100 & 739 & 99.2 \\
\hline & Jumlah & 149 & 100 & 149 & 100 & 149 & 100 & 149 & 100 & 149 & 100 & 745 & 100 \\
\hline
\end{tabular}


Berdasarkan Tabel 2., sebagian besar harapan mahasiswa terhadap pelayanan pendidikan sangat tinggi yaitu $98,7 \%$. Untuk dimensi pelayanan khususnya reliabilitas sangat tinggi $(99.3 \%)$, daya tanggap sangat tinggi $(97,9 \%)$, jaminan sangat tinggi $(98,7 \%)$, empati sangat tinggi $(97,9 \%)$, dan bukti fisik sangat tinggi (99.35\%).

\section{PEMBAHASAN}

Berdasarkan jawaban dari 149 mahasiswa, dengan memperhatikan frekuensi dari setiap dimensi pelayanan pendidikan, maka dapat dilihat pada Tabel 4., bahwa sebagian besar persepsi mahasiswa terhadap pelayanan pendidikan ada pada kategori cukup yaitu 53,4. Namun bila dilihat dari persepsi mahasiswa yang ada pada kategori
Berdasarkan Tabel 3., kepuasan mahasiswa terhadap pelayanan pendidikan sebagian besar tidak puas sebanyak $99.2 \%$. Dimensi pelayanan reliabilitas tidak puas $(100 \%)$, daya tanggap tidak puas $(99.3 \%)$, jaminan tidak puas (99.3\%), empati tidak puas $(97.3 \%)$ dan bukti fisik adalah tidak puas $(100 \%)$

kurang, jumlahnya tidak jauh berbeda dengan kategori baik, yaitu 44,4 \%, dengan perbedaan nilai $9 \%$. Nilai ini menunjukkan kesenjangan antara persepsi mahasiswa yang masuk pada kategori baik dan kurang hanya sedikit. Indikator yang menjadi bahan evaluasi pada tiap dimensi dapat dilihat pada tabel 4 dibawah ini :

Tabel 4. Presentase Pencapaian Skor Persepsi dan Harapan Pada Setiap Indikator dalam Dimensi Pelayanan Pendidikan.

\begin{tabular}{|c|c|c|c|c|c|c|c|}
\hline \multirow[b]{2}{*}{ No } & \multirow[b]{2}{*}{ Indikator } & \multicolumn{2}{|c|}{ Persepsi } & \multicolumn{2}{|c|}{ Harapan } & \multirow[b]{2}{*}{ Gap } & \multirow[b]{2}{*}{ Ket } \\
\hline & & $\begin{array}{l}\text { Skor } \\
(\%)\end{array}$ & Kategori & $\begin{array}{l}\text { Skor } \\
(\%)\end{array}$ & Kategori & & \\
\hline 1 & 2 & 3 & 4 & 5 & 6 & 7 & 8 \\
\hline 1 & $\begin{array}{l}\text { Kasus-kasus diberikan mendekati } \\
\text { nyata }\end{array}$ & 47,79 & Kurang & 96.91 & Sangat Tinggi & -49.12 & \multirow{7}{*}{$\begin{array}{l}R . \\
-29.84\end{array}$} \\
\hline 2 & $\begin{array}{l}\text { Dosen siap dalam memberikan } \\
\text { materi }\end{array}$ & 55.84 & Cukup & 96.64 & Sangat Tinggi & -40.8 & \\
\hline 3 & $\begin{array}{l}\text { Dosen dapat mempraktikkan ilmunya } \\
\text { ke dunia nyata }\end{array}$ & 51.41 & Cukup & 96.51 & Sangat Tinggi & -45.1 & \\
\hline 4 & $\begin{array}{l}\text { Dosen sering memberikan kasus- } \\
\text { kasus yang berhubungan dengan } \\
\text { dunia nyata }\end{array}$ & 53.15 & Cukup & 95.57 & Sangat Tinggi & -42.42 & \\
\hline 5 & Dosen mengajar sesuai jadwal & 46.71 & Kurang & 93.83 & Sangat Tinggi & -47.12 & \\
\hline 6 & $\begin{array}{l}\text { Soal ujian sesuai dengan materi yang } \\
\text { telah diberikan }\end{array}$ & 49.80 & Kurang & 94.36 & Sangat Tinggi & -44.56 & \\
\hline 7 & Dosen memberikan penilaian objektif & 57.18 & Cukup & 95.17 & Sangat Tinggi & -37.99 & \\
\hline 8 & $\begin{array}{l}\text { Ada kunjungan presentasi dari } \\
\text { Poltekkes ke perusahaan atau } \\
\text { instansi lain }\end{array}$ & 63.49 & Cukup & 91.28 & Sangat Tinggi & -27.79 & \multirow{9}{*}{$\begin{array}{l}\text { Daya } \\
\text { Tanggap }\end{array}$} \\
\hline 9 & $\begin{array}{l}\text { Dosen komunikatif dalam proses } \\
\text { perkuliahan }\end{array}$ & 57.32 & Cukup & 95.57 & Sangat Tinggi & -38.25 & \\
\hline 10 & $\begin{array}{l}\text { Staff Tata Usaha cepat dalam } \\
\text { menanggapi mahasiswa atau calon } \\
\text { yang membutuhkan bantuan }\end{array}$ & 57.45 & Cukup & 92.35 & Sangat Tinggi & -34.9 & \\
\hline 11 & $\begin{array}{l}\text { Staff Tata Usaha dapat memberikan } \\
\text { informasi dengan jelas }\end{array}$ & 57.85 & Cukup & 90.47 & Sangat Tinggi & -32.62 & \\
\hline 12 & $\begin{array}{l}\text { Staff Tata Usaha melakukan } \\
\text { pekerjaannya dengan cepat }\end{array}$ & 61.61 & Cukup & 89.80 & Sangat Tinggi & -28.19 & \\
\hline 13 & Pekarya cepat memberikan informasi & 61.48 & Cukup & 90.34 & Sangat Tinggi & -28.86 & \\
\hline 14 & Proses pemeriksaan nilai cepat & 51.01 & Cukup & 94.23 & Sangat Tinggi & -43.22 & \\
\hline 15 & Nilai diberitahukan dengan rinci & 56.64 & Cukup & 94.09 & Sangat Tinggi & -37.45 & \\
\hline 16 & $\begin{array}{l}\text { Mudah dalam mendapatkan materi } \\
\text { perkuliahan (handout dll) }\end{array}$ & 53.56 & Cukup & 94.77 & Sangat Tinggi & -41.21 & \\
\hline
\end{tabular}




\begin{tabular}{|c|c|c|c|c|c|c|c|}
\hline 1 & 2 & 3 & 4 & 5 & 6 & 7 & 8 \\
\hline 17 & $\begin{array}{l}\text { Materi perkuliahan yang diberikan } \\
\text { berbobot }\end{array}$ & 56.51 & Cukup & 96.38 & Sangat Tinggi & -39.87 & \multirow{7}{*}{$\begin{array}{l}\text { Jaminan } \\
-36.24\end{array}$} \\
\hline 18 & $\begin{array}{l}\text { Kurikulum yang ditawarkan } \\
\text { bermanfaat untuk kerja }\end{array}$ & 46.85 & Kurang & 95.30 & Sangat Tinggi & -48.45 & \\
\hline 19 & $\begin{array}{l}\text { Komposisi antara teori dengan } \\
\text { praktik seimbang }\end{array}$ & 48.86 & Kurang & 94.23 & Sangat Tinggi & -45.37 & \\
\hline 20 & $\begin{array}{l}\text { Mata kuliah konsentrasi banyak } \\
\text { pariasinya }\end{array}$ & 64.83 & Cukup & 81.74 & Sangat Tinggi & -16.91 & \\
\hline 21 & $\begin{array}{l}\text { Alumni mudah dalam mendapatkan } \\
\text { pekerjaan }\end{array}$ & 55.44 & Cukup & 97.32 & Sangat Tinggi & -41.88 & \\
\hline 22 & $\begin{array}{l}\text { Kesesuaian biaya dengan kualitas } \\
\text { yang ditawarkan }\end{array}$ & 51.54 & Cukup & 94.23 & Sangat Tinggi & -42.69 & \\
\hline 23 & Lokasi Poltekkes mudah dijangkau & 68.59 & Cukup & 93.42 & Sangat Tinggi & -24.83 & \\
\hline 24 & $\begin{array}{l}\text { Tersedianya transfortasi umum untuk } \\
\text { menjangkau lokasi Poltekkes }\end{array}$ & 69.66 & Cukup & 93.56 & Sangat Tinggi & -23.9 & \multirow{9}{*}{$\begin{array}{l}\text { Empati } \\
-37.72\end{array}$} \\
\hline 25 & $\begin{array}{l}\text { Dosen dapat memberikan materi } \\
\text { dengan baik dan jelas }\end{array}$ & 54.90 & Cukup & 98.39 & Sangat Tinggi & -43.49 & \\
\hline 26 & Dosen memiliki pengetahuan luas & 59.33 & Cukup & 98.52 & Sangat Tinggi & -39.19 & \\
\hline 27 & Staff Tata Usaha ramah & 59.46 & Cukup & 91.54 & Sangat Tinggi & -32.08 & \\
\hline 28 & $\begin{array}{l}\text { Ada customer service yang dapat } \\
\text { memberikan keterangan tentang } \\
\text { Poltekkes secara langsung }\end{array}$ & 52.75 & Cukup & 87.79 & Sangat Tinggi & -35.04 & \\
\hline 29 & Proses mendaftar mudah & 60.54 & Cukup & 94.77 & Sangat Tinggi & -34.23 & \\
\hline 30 & $\begin{array}{l}\text { Proses menginput mata kuliah untuk } \\
\text { semester berikutnya mudah }\end{array}$ & 61.21 & Cukup & 94.90 & Sangat Tinggi & -33.69 & \\
\hline 31 & Waktu kuliah konsisten & 51.14 & Cukup & 93.29 & Sangat Tinggi & -42.15 & \\
\hline 32 & $\begin{array}{l}\text { Ada pemberitahuan sebelumnya bila } \\
\text { perkuliahan ditiadakan atau diundur }\end{array}$ & 52.08 & Cukup & 95.57 & Sangat Tinggi & -43.49 & \\
\hline 33 & $\begin{array}{l}\text { Ada poster / spanduk yang mudah } \\
\text { dilihat dan jelas tentang pembukaan } \\
\text { pendaftaran mahasiswa baru }\end{array}$ & 55.84 & Cukup & 93.69 & Sangat Tinggi & -37.85 & \multirow{13}{*}{$\begin{array}{l}\text { Bukti } \\
\text { Fisik } \\
-35.89\end{array}$} \\
\hline 34 & $\begin{array}{l}\text { Disediakan brosur bagi peminat } \\
\text { masuk di Poltekkes }\end{array}$ & 58.66 & Cukup & 94.50 & Sangat Tinggi & -35.84 & \\
\hline 35 & $\begin{array}{l}\text { Ada iklan di koran tentang } \\
\text { pembukaan pendaftaran bagi } \\
\text { mahasiswa baru }\end{array}$ & 54.90 & Cukup & 87.11 & Sangat Tinggi & -32.21 & \\
\hline 36 & $\begin{array}{l}\text { Dosen berpakaian rapih saat } \\
\text { memberikan kuliah }\end{array}$ & 58.59 & Kurang & 96.38 & Sangat Tinggi & -37.79 & \\
\hline 37 & $\begin{array}{l}\text { Staff Tata Usaha berpakaian rapih } \\
\text { saat bekerja }\end{array}$ & 61.35 & Cukup & 89.93 & Sangat Tinggi & -28.58 & \\
\hline 38 & $\begin{array}{l}\text { Pekarya mengenakan pakaian yang } \\
\text { rapih }\end{array}$ & 64.70 & Cukup & 90.87 & Sangat Tinggi & -26.17 & \\
\hline 39 & $\begin{array}{l}\text { Tersedia alat bantu pendidikan, } \\
\text { komputer / infokus / LCD yang layak } \\
\text { pakai }\end{array}$ & 57.05 & Cukup & 96.78 & Sangat Tinggi & -39.73 & \\
\hline 40 & $\begin{array}{l}\text { Tersedia buku-buku edisi baru } \\
\text { diperpustakaan }\end{array}$ & 60.54 & Cukup & 91.81 & Sangat Tinggi & -31.27 & \\
\hline 41 & $\begin{array}{l}\text { Tersedia buku dalam jumlah yang } \\
\text { cukup banyak untuk buku-buku yang } \\
\text { sering digunakan }\end{array}$ & 62.95 & Cukup & 95.70 & Sangat Tinggi & -32.75 & \\
\hline 42 & $\begin{array}{l}\text { Ada gedung khusus bagi mahasiswa } \\
\text { D.III / D.IV }\end{array}$ & 54.50 & Cukup & 92.35 & Sangat Tinggi & -37.85 & \\
\hline 43 & $\begin{array}{l}\text { Ada perpustakaan yang dapat } \\
\text { diakses lewat internet sehingga } \\
\text { memudahkan mencari data }\end{array}$ & 56.78 & Cukup & 93.83 & Sangat Tinggi & -37.05 & \\
\hline 44 & Meja dan kursi kuliah yang nyaman & 61.07 & Cukup & 92.62 & Sangat Tinggi & -31.55 & \\
\hline 45 & Ruang kelas yang bersih untuk kuliah & 59.60 & Cukup & 94.90 & Sangat Tinggi & -35.3 & \\
\hline
\end{tabular}




\begin{tabular}{clccccc}
\hline $\mathbf{1}$ & \multicolumn{1}{c}{$\mathbf{2}$} & $\mathbf{3}$ & $\mathbf{4}$ & $\mathbf{5}$ & $\mathbf{6}$ & $\mathbf{7}$ \\
\hline 46 & $\begin{array}{l}\text { Tersedia air conditioning (AC) } \\
\text { diruang kelas }\end{array}$ & 50.07 & Cukup & 97.45 & Sangat Tinggi & -47.38 \\
\hline 47 & $\begin{array}{l}\text { Tersedia lahan parkir kendaraan } \\
\text { yang luas }\end{array}$ & 62.82 & Cukup & 92.89 & Sangat Tinggi & -30.07 \\
\hline 48 & $\begin{array}{l}\text { Tersedia kantin yang bersih dengan } \\
\text { makanan yang bervariasi }\end{array}$ & 54.36 & Cukup & 91.68 & Sangat Tinggi & -37.32 \\
\hline 49 & Tersedia ruang makan & 52.89 & Cukup & 86.04 & Sangat Tinggi & -33.15 \\
\hline 50 & Tersedia ruang diskusi & 54.90 & Cukup & 87.92 & Sangat Tinggi & -33.02 \\
\hline 51 & WC yang bersih & 55.03 & Cukup & 97.05 & Sangat Tinggi & -42.02 \\
\hline 52 & Tersedia hotspot . wifi & 48.86 & Kurang & 99.87 & Sangat Tinggi & -51.01 \\
\hline & Rata-rata & $\mathbf{5 4 . 6 8}$ & Cukup & $\mathbf{9 1 . 7 1}$ & Sangat Tinggi & $\mathbf{- 3 7 . 0 3}$ \\
\hline
\end{tabular}

Sumber : Data Primer, 2014

Tabel 4 menggambarkan, tidak ada pencapaian skor persepsi pada Indikator dalam dimensi pelayanan pendidikan dalam kategori baik. Pelayanan yang berada pada kategori kurang meliputi soal-soal / kasuskasus yang diberikan mendekati nyata, dosen mengajar sesuai jadwal, dosen memberikan soal ujian sesuai dengan materi yang telah diberikan, kurikulum yang ditawarkan bermanfaat untuk kerja, komposisi antara teori dengan praktik atau penerapan kedunia nyata seimbang dan tersedia hotspot / wifi. Indikator pelayanan yang lainnya ada dalam kategori cukup.

Skor soal / kasus yang diberikan mendekati nyata sejalan dengan skor komposisi antara teori dan praktik atau penerapan kedunia nyata, keduanya ada dalam kategori kurang. Hal ini sesuai dengan evaluasi pengguna (user) termasuk staekholder atau pengguna lulusan di Puskesmas, Rumah Sakit dan Bidan Praktik Swasta yang mengungkapkan bahwa keterampilan yang dimiliki oleh lulusan masih perlu peningkatan karena pada saat dilapangan, lulusan mendapatkan atau menghadapi kasus-kasus patologis, lulusan belum dapat mengaplikasikan keterampilannya secara maksimal, sehingga penatalaksanaan pada kasus-kasus patologi cenderung kurang dan perlu banyak belajar studi kasus untuk dapat dengan cepat dan tepat menentukan keputusan klinik yang harus lulusan ambil segera.

Indikator dosen mengajar sesuai jadwal mendapat skor dalam kategori kurang, peneliti mengkaji ulang dengan melakukan wawancara kepada beberapa mahasiswa untuk mendapatkan informasi tentang hal tersebut. Peneliti menyimpulkan, hal demikian terjadi karena adanya keterbatasan Sumber Daya Manusia (SDM) khususnya dosen dalam menyampaikan mata kuliah, artinya terdapat beban mengajar dosen yang belum merata sehingga yang terjadi kekosongan jam mengajar di satu kelas karena pada jam yang sama dosen terkait harus mengajar di kelas lain dengan mata kuliah yang berbeda.

Keberadaan hotspot / wifi memang memegang peranan yang sangat penting dalam menunjang mahasiswa untuk dapat melakukan studi literatur melalui internet untuk melengkapi tugas yang diberikan oleh institusi pendidikan terkait dengan proses pembelajaran. Selain mahasiswa dapat mengakses literatur melalui perpustakaan yang sudah tersedia di Program Studi yang skor indikatornya ada pada kategori cukup, mahasiswa pun diharapkan dapat mengakses jurnal penelitian hasil evidence based yang tentunya sangat bermanfaat karena setiap saat ilmu itu selalu berkembang.

Harapan mahasiswa terhadap ketersediaan hotspot tinggi, namun persepsinya kurang. Setelah mengikuti 
proses perkuliahan, barulah mahasiswa dapat menilai tentang apa yang ia lihat. Hal ini adalah persepsi, sesuai yang disampaikan oleh Sobur (2009) bahwa menurut Atkinson bahwa persepsi muncul ketika seseorang melewati proses saat ia mengorganisasi dan menafsirkan stimulus dalam lingkungan.Sesuai dengan penelitian Maelani (2011) menjelaskan bahwa kinerja cukup baik, harapan sangat tinggi namun dari segi kepuasan termasuk dalam kategori kecewa.

Persepsi yang kurang baik juga dapat dilihat pada indikator komposisi antara teori dengan praktik atau penerapan kedunia nyata seimbang dalam dimensi jaminan. Skor dalam indikator ini adalah 48,86. Munculnya persepsi kurang baik mungkin disebabkan oleh banyaknya institusi kebidanan lain yang mempunyai kurikulum yang sama dan agenda praktik yang sama, sehingga terdapat penumpukan mahasiswa dilahan praktik. Sampai saat ini, institusi kebidanan di Wilayah III Cirebon berjumlah 8 institusi, yang sebagian besar menggunakan lahan praktik yang sama dengan Prodi Kebidanan Cirebon. Namun demikian, hal ini dapat diatasi dengan melatih softskill dari mahasiswa dan meningkatkan hardskil terkait dengan pemberian asuhan berkesinambungan yang sesuai dengan teori dan keterampilan dalam penatalaksanaan kasus pada semua pasien. Sehingga pengguna / user dapat menilai secara objektif akan kemampuan mahasiswa menangani pasien dari segi softskill dan hardskill nya. Sesuai dengan yang diungkapkan Muklas (1999) bahwa nilai ataupun sikap seseorang terhadap sesuatu akan mempengaruhi motivasi individu dalam mengambil keputusan untuk meningkatkan produktifitas atau sebaliknya.

Fasilitas di setiap kelas adanya Air Conditioning (AC) dengan harapan mahasiswa akan merasa nyaman mengikuti proses pembelajaran sehingga mempengaruhi pencapaian hasil studi yang maksimal. Namun dalam kenyataannyan, dari harapan yang sangat tinggi tentang AC yaitu $97.45 \%$, namun dari persepsi pencapaiannya ada lam kategori cukup dan cenderung kurang dengan skor 50,07 \%. Peneliti berpendapat bahwa, keberadaan AC di setiap ruangan kelas dalam keadaan sebenarnya memang tidak bekerja secara maksimal, sebagian keluhan mahasiswa adalah ada AC yang tidak dingin, namun keluhan ini sudah ditanggapi oleh pendidikan dengan memanggil penyedia layanan service AC.

Menurut Djamarah (2000) bahwa kondisi fisiologis dapat berpengaruh terhadap kemampuan belajar seseorang, orang dalam keadaan nyaman dan segar akan berlainan belajarnya dengan orang dalam keadaan kelelahan atau situasi lingkungan yang tidak nyaman. Mahasiswa merasa nyaman dengan kondisi ruangan yang dingin dengan jumlah AC yang cukup, akan menunjang terhadap kemampuan belajar mahasiswa dalam menerima setiap mata kuliah yang disampaikan dosen. Masih menurut Djamarah (2000), mengungkapkan bahwa lingkungan sangat mempengaruhi proses dan hasil belajar.

Tabel 4 , sebagian besar harapan mahasiswa terhadap pelayanan pendidikan adalah sangat tinggi yaitu $98.7 \%$. Untuk setiap dimensi pelayanan menunjukkan bahwa sebagian besar harapan mahasiswa terhadap dimensi reliabilitas adalah sangat tinggi sebanyak 148 (99.3\%) mahasiswa, untuk dimensi daya tanggap adalah sangat tinggi sebanyak 146 (97.9\%) mahasiswa, untuk dimensi jaminan adalah sangat tinggi sebanyak 147 (98.7\%) mahasiswa, untuk dimensi empati adalah sangat tinggi sebanyak 146 (97.9\%) mahasiswa, dan untuk dimensi bukti fisik adalah sangat tinggi sebanyak 148 (99.35\%) mahasiswa. Hal tersebut menggambarkan bahwa, mahasiswa menyimpan harapan yang sangat tinggi terhadap kualitas pelayanan pendidikan.

Tabel 1, hampir semua dimensi pelayanan perlu ditingkatkan, karena dari hasil pengolahan data, harapan mahasiswa terhadap pelayanan pendidikan masih lebih tinggi dibandingkan dengan persepsi mahasiswa terhadap pelayanan pendidikan. Oleh karena itu, perlu bagi Program Studi Kebidanan Cirebon meningkatkan pelayanan pendidikan, karena dampaknya tidak hanya pada kualitas pendidikan yang akan lebih 
baik, tapi juga sebagai promosi dalam perkembangan kedepannya .

Tabel 4, tampak kesenjangan antara persepsi dan harapan. Secara keseluruhan, kesenjangan per indikator ada pada kategori tidak puas karena pengurangan antara persepsi dan harapan menghasilkan nilai negatif. Kesenjangan tertinggi adalah untuk dimensi empati yaitu - 37,72, untuk dimensi reliabilitas kesenjangannya adalah $-29,84$, dimensi daya tanggap kesenjangannya adalah -34,72, dimensi jaminan kesenjangannya adalah $-36,24$ dan dimensi bukti fisik kesenjangannya adalah $-35,89$. Secara keseluruhan tingkat kepuasan mahasiswa terhadap pelayanan pendidikan di Prodi Kebidanan Cirebon ada pada kategori tidak puas.

Menurut Rangkuti (2002), kesenjangan merupakan ketidaksesuaian antara kenyataan pelayanan yang didapatkan (perceived service) dengan pelayanan yang diharapkan (expected service). Kesenjangan terjadi apabila pelanggan merasa kenyataan pelayanan yang diterimanya lebih tinggi dari pada desired service atau lebih rendah dari adequate service harapan pelangan tersebut. Dengan demikian pelanggan dapat merasakan sangat puas atau sebaliknya. Kesenjangan antara perceived service dengan expected service menurut Gap Model of Service Quality (Parasuraman, Zeithaml, dan Berry, 1985).

Dalam dimensi reliabilitas seluruh indikator mendapatkan nilai kesenjangan negatif. Hal ini menunjukkan bahwa

\section{KESIMPULAN}

Persepsi mahasiswa terhadap pelayanan pendidikan sebagian besar adalah cukup. Harapan mahasiswa terhadap pelayanan pendidikan sebagian besar adalah

\section{SARAN}

Meningkatkan pelayanan pendidikan kepada mahasiswa dengan didasari oleh harapan mahasiswa, serta memaksimalkan menindaklanjutinya dengan ada komunikasi terjadwal diantara civitas akademika, mahasiswa memiliki kenyataan bahwa pelayanan pendidikan Prodi Kebidanan belum sesuai dengan yang diharapkan. Demikian juga dengan nilai indikator yang lainnya, Dari keseluruhan indikator, kesenjangan terendah terdapat pada dimensi jaminan yaitu indikator pariasi konsentrasi mata kuliah dengan nilai 16,91, dan kesenjangan tertinggi ada pada dimensi bukti fisik .dengan indikator hotspot atau jaringan internet yaitu dengan nilai kesenjangan $-51,01$.

Beberapa indikator dengan kesenjangan tertinggi diantaranya keadaan WC, keberadaan $A C$ di ruang kelas, dosen mengajar sesuai jadwal, proses pemeriksaan nilai, alumni mudah mendapatkan kerja, waktu kuliah konsisten dan ada pemberitahuan sebelumnya bila perkuliahan diundur. Kebersihan kamar mandi (WC) dalam dimensi bukti fisik ada pada kategori tidak puas, peneliti berpendapat bahwa hal ini terjadi karena kurangnya tenaga cleaning service (CS). Saat ini di Prodi Kebidanan ada 2 orang tenaga CS dengan beban kerja membersihkan 9 kamar mandi dengan jumlah pengguna seluruh mahasiswa serta karyawan yaitu sejumlah 221 orang..

Kesesuaian jadwal mengajar dosen yang mendapat penilaian tidak puas pada dimensi reliabilitas dapat disebabkan tingginya beban kerja dosen, sehingga dalam waktu yang bersamaan, dosen dapat mengajar di dua kelas yang berbeda. Untuk mengisi jadwal yang tertinggal maka dosen meminta waktu mengajar di hari yang berbeda.

sangat tinggi. Kepuasan mahasiswa terhadap pelayanan pendidikan di Prodi Kebidanan Cirebon sebagian besar ada pada kategori tidak puas

Perlunya kunjungan atau study banding ke institusi pendidikan setingkat yang memiliki kualitas pelayanan pendidikan yang lebih baik. 


\section{DAFTAR PUSTAKA}

Banar F. A.,i (2012), Tinggi Harapan Masyarakat pada Layanan Pendidikan

Berry, L, and Parasuraman (1991), Marketing Service Copeting Through Quality, New York : The Free Press

Djamarah, S.B., (2000), Psikologi Belajar, Edisi 2, Rineka Cipta, Jakarta. Fandy Tjiptono (2001), Riset Pemasaran : Konsep dan Aplikasi dengan SPSS, PT. Elex Media Komputindo, Jakarta , (2011), Pemasaran Jasa, Malang : Bayumedia Publising

Srinadi, I.G.A.D., dan Nilakusumawati, D.K., (2008). Faktor-faktor penentu kepuasan mahasiswa terhadap pelayanan fakultas sebagai lembaga pendidikan (Studi Kasus di FMIKPA, Universitas Udayana), Bali : Jurnal Cakrawala Pendidikan, November 2008, Tahun XXVII No. 3 Laporan Kepuasan Mahasiswa Pada Program Studi Kebidanan Cirebon (2013 /2014)

Muchlas, M.(1999), Organizational Behavior, UGM, Yogyakarta

Rambat L., (2008), Manajemen Pemasaran Jasa, edisi 2, Jakarta, Salemba Empat

Rangkuti, F. 2002. Measuring Customer Satisfaction: Teknik Mengukur dan Strategi Peningkatan Kepuasan
Pelanggan. Gramedia Pustaka Utama, Jakarta.

Rizky G., (2012), Tingkat Kepuasan Mahasiswa Terhadap Pelayanan Pendidikan di Jurusan Pendidikan Fakultas Ekonomi, Universitas Negeri Yogjakarta, Skripsi, Universitas Negeri Yogyakarta.

Robbins P, dan Stephen (2001), Penilaian Organisasi, Prentice Hall, Edisi Kesembilan

Sadat, A.M, (2000), Analisis Hubungan Kinerja Jasa Perguruan tinggi Terhadap Kepuasan Mahasiswa : Studi Kasus Universitas Indonesia, Program Pasca Sarjana IImu Ekonomi dan Manajemen UI, Jakarta

Sobur A., (2009), Psikologi Umum. CV. Pustaka setia, Bandung.

Sugiyono, (2010), Metode Penelitian Bisnis, Alfabeta, Bandung

Arikunto, S., (2010), Prosedur Penelitian Suatu Pendekatan Praktik, Jakarta, Rineka Cipta

Wahyani, W., (2010), Penerapan Metode Service Quality untuk Menganalisis Kepuasan Pelanggan, Skripsi Jurusan Teknik Industri, Fakultas Teknologi Industri, Institut Teknologi Adhi Tama, Surabaya 